to proxy fights where issues are reasonably related to corporate velfare.43 And reasonableness should depend on not only the issues involved, but the insurgents' good faith, the strength of shareholder support enlisted, and the type and amount of expenditure. ${ }^{44}$ With the sanction of such case-by-case determination, stockholders will be discouraged from extravagant and capricious campaigning. An outright reasonableness test, therefore, is a more valid measure than the "policy-reasonable cost" standard and can effectively control solicitation expenditures.

Two methods are available for judicial enforcement of losing dissenters' reimbursement claims. In a direct suit by the losers against the corporation payment might be ordered. ${ }^{45}$ Or courts could indirectly enforce payment by enlarging management's derivative suit liability. Thus they could hold management's outlay unreasonable and compel restitution to the corporate treasury unless the losers' reasonable claims were honored by management,

43. Cf. Hall v. Translux Daylight Picture Screen Corp., 20 Del. Ch. 78, 171 Atl. 226 (Ch. 1934) (merger and stock dividend); Hand v. Mfissouri-Kansas Pipe Line Co., 54 F. Supp. 649 (D.Del. 1944) (plan for liquidation); Empire Southern Gas Co. v. Gray, 46 A.2d 741 (Del. Ch. 1946) (merger or maintaining cestly suite of offices); Peel v. London \& N.W. Ry. Co., [1907] 1 Ch. Div. 5 (1906) (confercnee on interrailway cooperation, use of larger railway cars, and more elaborate statistical system). See also Emerson \& Latcham, supra note 16 (management's record of neglect and poor performance). Two types of issue which may be involved in an election contest can be distinguished: the directors may be challenged because they stand for particular policies whose desirability for the future is questioned, or because they stand for a record of performance whose promise for the future is doubted. Issues of the latter type, though difficult to cast into the mold of a "policy" formula, would seem at least equal to the former in potential importance to corporate welfare.

44. No court has yet held any expenditures improper in a "policy" contest. When courts are convinced that nothing more is involved than the spoils of corporate ofice, however, their scrutiny becomes closer. In such cases, the tendency has been to limit expenditures of corporate funds by declaring improper the means of solicitation principally employed. Pittsburgh Steel Co. v. Walker, 92 PrTrs. Leg. J. 464 (C.P. Alleghany County 1944) (employment of professional proxy solicitors); Lawyers' Advertising Co. v. Consolidated Ry. L. \& R. Co., 187 N.Y. 395, S0 N.E. 199 (1907) (newspaper advertisements); but of., In re Zickl, 73 N.Y.S.2d 181 (Sup. Ct. 1947) (employment of professional proxy solicitors held "entirely proper" without discussion of nature of issues). Use of professional proxy solicitors is apparently standard practice today. See Regulation X-14, Schedule 14A, Item 3.

45. Cost reimbursement of successful plaintiffs in derivative suits may afiord useful precedent. Cf. Sprague v. Ticonic National Bank, 307 U.S. 161 (1939); Cannon v. Parker, 151 F.2d 706 (5th Cir. 1945). See Note, 36 Corwelc L.Q. 558 (1951). In such cases; no separate suit for cost recovery need te brought, however. The award is usually made as a part of the adjudication in which the claim to it arises. But see N.Y. GEx. CORP. LAw $\$ 65$ (permitting separate suit). Mloreover, it is usually made "out of' the particular fund or property which is the subject of the original suit. Altematively, losing dissenters might seek to recover at law in quasi-contract. See DAwso:z, U::Juss ENRICHASENT 113 (1951): "[T]here is nothing in our presunt conceptions that prevalit; an appropriate unjust enrichment remedy from being used in any fisld." 
either before suit or after a decree so conditioned. ${ }^{40}$ This device is preferable $^{47}$ because it would ordinarily assure reimbursement without litigation. Yet the legitimacy of contestants' disbursements can still be judicially tested. If management doubts the reasonableness of insurgents' outlays, it may refise repayment though its own proxy costs are paid by the corporation. Inst1rgents could then bring a derivative suit. In such case, the reasonableness of both management's and insurgents' expenditures would be stibjected to judicial scrutiny. On the other hand, if management too readily acquiesces in the losers' claims, other shareholders can, in a derivative stit, force it to repay all unreasonable proxy solicitation outlays of both sides.

\section{TOWARD CERTAINTY IN THE EXTRATERRITORIAL EFFECT OF DIVORCE DECREES*}

A SEEMINGLY valid divorce granted in one state may have to stand the test of collateral challenge in another state. ${ }^{1}$ If the divorced couple have both

46. Equity can readily fashion alternative or conditional decrees. See, c..., McCandless v. Furlaud, 296 U.S. 140 (1935) ; Hayward v. Leeson, 176 Mass. 310, 57 N.E. 656 (1900).

47. Statutory restrictions often impede bringing derivative suits. See N.Y. GEN. CORP. LAW $\$ 61$ (contemporaneous ownership), $\$ 61-b$ (security for costs); cf. Weinstcin v. Behn, 65 N.Y.S.2d 536 (Sup. Ct. 1946), 68 N.Y.S.2d 199 (Stup. Ct. 1947), aff'l m'm, 272 App. Div. 1045, 75 N.Y.S.2d 284 (1st Dep't 1947), appeal denied, 273 App. Div. 877, 77 N.Y.S.2d 391 (1st Dep't 1948), appeal dismissed, 298 N.Y. 506, 80 N.E.2d 656 (1948). See also note 20 supra. But the mere possibility of derivative suit here may lead' to solicitation cost recovery without litigation. Moreover, the "contemporanteous ownership" rule will be no bar to actual suit. The gravamen of plaintiffs' complaint is management's wrongful failure to reimburse them for reasonable proxy solicitation expenditures. Thus they typically are shareholders at the time of the wrong complained of. Nor should any requirement of prior demand on management and sharcholders hinder action. Cf. Delaware \& Hudson Co. v. Albany \& Susquehanna R. Co., 213 U.S. 435 (1909). And "security for costs" statutes can be hurdled by joinder of sufficient plaintiffs, aggregating their stock ownership to meet statutory requirements. Baker v. MacFadden Publications, Inc., 300 N.Y. 325, 90 N.E.2d 876 (1950). Furthermore, plaintiffs having any reasonable claim for reimbursement should almost automatically win. Thus, even if bond for defendants' costs were posted, there would be no liability on it. See Stevens, Corporations \$ 174 (2d ed. 1949).

*Johnson v. Muelberger, 340 U. S. 581 (1951).

1. In an attack of this nature, the divorce is generally pleaded defensively as a bar to the plaintiff's claim. E.g., Matter of Lindgren's Estate, 293 N.Y. 18, 55 N.E.2d 849 (1944); In re Davis' Estate, 38 Cal. App. 2d 579, 101 P.2d 761 (1940); see also Jacobs, Attack on Decrees of Divorce, 34 Micr. L. Rev. 749 (1936); id. at 959. The plaintiff must demand that the court hold the foreign decree invalid and of no binding effect in the present forum. He invokes the court's power to reexamine the jurisdictional basis of the foreign decree. Williams v. North Carolina, 325 U.S. 226 (1945).

Jurisdiction to render a decree of divorce is founded upon the bona fide domicile of at least one party. Goodricri, Conflict of LAws $\$ \S 128,131$ (3d ed. 1949). Jurisdiction over one party is said to give the court jurisdiction over the "res" of the marriage. The in rem character of the adjudication makes it "binding on the whole 
come under the jurisdiction of the court which granted the decree,? res judicata precludes these parties from attaching the decree collaterally. 3 But sometimes the challenger is a third person with an injured right or interest." If he is not so closely identified with the divorcees as to be termed "in privity" with them, res judicata will not bar a collateral attack by him.5

The measure of privity, however, is not a precise one. Jurisdictions may differ on the standing of a third person to challenge a divorce decree. ${ }^{0}$ Thus, a

world," which of course include the other party. Domicile for divorce purposes is in turn dependent upon two factors: a statutory period of residence within the state and the highly illusory "intent" to make it the party's "home" Goonarce, Cosifler or Lilys 64 (3d ed. 1949). Thus if one is not careful to provide the outward signs of such an intention, courts in other states frequently find no bonz fide domicile, hence no jurisdiction in the granting court, hence an invalid divorce. E.g., Smerda v. Smerda, 74 N.E.2d 751 (Ohio C.P. 1947); Lynch v. Lynch, 210 Mfiss. 810, 50 So.2d 378 (1951); Myers v. Connor, 93 N.Y.S.2d 623 (Sup. Ct. 1949).

2. A court may acquire jurisdiction over the defendant if he is domicilcd within the state, personally served within the state, or if he appears before the court. Lynn $v$. Lynn, 302 N.Y. 193, 97 N.E.2d 748 (1951); Shea v. Shea, 270 App. Div. 527, 60 N.Y.S.2d S23 (2d Dep't 1946). See Goodrucr, Confuct of Laws 187 (3d ed. 1949); Harper, The Myth of the Void Divorce, 2 Law \& CoNTearp. Pros. 335, 336 (1935).

3. See Sherrer v. Sherrer, 33t U.S. 343, 350 (1948): "res judicata applies to adjudications relating either to jurisdiction of the person or of the subject matter where such adjudications have been made in proceedings in which those questions were in issue and in which the parties were given full opportunity to litigate" See also Coa v. Coe, 334 U. S. 378 (1948) ; Davis v. Davis, 305 U.S. 32 (193S) ; Comment, Divoree Jurisdiction By Consent of the Parties-Dea'elopments Since "Sherrer v. Sherrer," 26 IND. L.J. 380 (1951).

4. Some courts limit a third person's right to attack collaterally to situations where his interest existed prior to the former judgment and was injured at the time the decree was rendered. See 1 Fremaran, Judgarents 636, \$319 (5th ed. 1925); de Mrarigny v. de Mlarigny, 43 So.2d 412, 447 (Fla. 1949); Gaylord v. Gaylord 45 So.2d 507, 509 (Fla. 1950); State $e x$ rel. Van Hafften v. Ellison, 285 Mfo. 301, 316, 226 S.IW. 559, $563(1920)$.

The more general rule is that the third party attacker must simply show at the time of his suit that he suffers injury by the decree. Urquhart v. Urqubart, 272 App. Div. 60, 69 N.Y.S.2d 57 (1st Dep't 1947), aff'd 297 N.Y. 6S9, 77 N.E.2d 7 (1947); Old Colony Trust Co. v. Porter 324 Mass. 581, 589, \&8 N.E.2d 135, 140 (1949); Ex Parte Nimmer, 212 S.C. 311, 319, 47 S.E.2d 716, 717 (1948).

5. Ainscow v. Alexander, 28 Del. Ch. 545, 39 A.2d 54 (Ch. 1944); Miatter of Lindgren's Estate, 293 N.Y. 18, 55 N.E.2d $\$ 49$ (1944). See also France v. Freeze, 4 Wash.2d 120, 102 P.2d 687 (1940).

"Privity" was defined by the Supreme Court in Bigclow v. Old Dominion Mining \& Smelting Co., 225 U.S. 111, 129 (1912), as "mutual or successive relationship to the same right of property." There have been several minor variations in the vording of the definition; but all attempt to denote a degree of aftinity with the interests of the primary parties such that the interest or right adjudicated and that sulisequently claimul, are substantially the same 1 FreErLAN, JudGarents 959, $\$ 43 S$ (5th ed. 1925) (Cases cited).

6. Compare Estate of Davis, 3S Cal. App. 2d 579, $5 \$ 5$ (1940) where the curt states, "As a general rule, an heir being in privity with the ancestor is bound by an estoppal which was binding upon the ancestor." with MLatter of Lindgren 293 N.Y. 18, 55 N.E.2.1 
particular challenger may be estopped as a privy by the state which rendered the decree but permitted to attack under the law of the state in which his suit is brought. Does the Full Faith and Credit clause, in dictating that the decree of one state shall have uniform effect in all states, ${ }^{7}$ require that the rule of the state which granted the divorce determine the standing of potential challengers in all states? In the past the requirement of full faith has not been considered applicable to this determination. Customarily, courts have not relied on the law of the granting state in measuring the standing of the third party attacker. ${ }^{8}$

Johnson v. Muelberger upset this practice. ${ }^{0}$ There the daughter by a first marriage tried to prevent her deceased father's third wife from claiming her widow's statutory share of the estate. ${ }^{10}$ The entire estate had been willed to the daughter. She maintained that her father's divorce from his second wife in Florida was invalid and hence his subsequent marriage void. Since the father had entered a general appearance in the Florida action, the decree was res judicata as to him. The New York Court of Appeals, noting that the daughter was not in privity with her father, allowed the attack.11 But the Supreme Court reversed. It determined that Florida law would bar the daughter's challenge ${ }^{12}$ and held that, under the Full Faith and Credit clause, that bar

849 (1944) where it was held that a daughter was not in privity with her father and therefore not subject to the disability that he bore.

7. U. S. Const. ART. IV, § 1: "Full Faith and Credit shall be given in each state to the Public Acts, Records, and Judicial Proceedings of every other state." For the only legislative interpretation of the Clause, see Act of 1790, 28 U.S.C. $\S 1738$ (1948).

8. See Ainscow v. Alexander, 28 Del. Ch. 545, 555, 39 A.2d 54, 58 (Ch. 1944); In rc Brandt's Estate, 67 Ariz. 42, 45, 190 P.2d 497, 499 (1948); Mumma v. Mumma, 86 Cal. App.2d 133, 136, 194 P.2d 24, 26 (1948).

A survey of the cases reveals a notable absence from the opinions of citations to cases of the state which rendered the divorce on the question of the standing of a third person to challenge.

The question of full faith and credit generally does not arise until after the court has found the foreign court to have had jurisdiction to render the decree. Only then is the local court obliged to extend full faith and credit to the foreign adjutication. Williams v. North Carolina, 325 U.S. 226 (1945). See also Runyan, The Problcm of Migratory Divorce, 37 A.B.A.J. 12 (1951).

9. 340 U.S. 581 (1951).

10. Notice of her election to take her intestate share of the decedent's estate was filed under $\$ 18$ of the Decedents' Estate Law of the State of New York.

11. In re Johnson's Estate, 301 N.Y. 13, 92 N.E.2d 44 (1950).

A Florida case, State ex rel. Willys v. Chillingworth, 124 Fla. 274, 168 So. 249 (1936), was also mentioned as permitting the daughter's collateral attack in Florida. However the case was not directly in point since the question of res judicata was not involved.

12. The Court read two recent Florida cases to bar the daughter's attack on either of two alternative theories: "If the laws of Florida should be that a surviving child is in privity with its parent as to that parent's estate, surely the Florida doctrine of res judicata would apply to the child's collateral attack as it would to the father's. If on the other hand, Florida holds, as New York does in this case, that the child of a former 
must also operate in New York. The New York law on the point made no appearance in the opinion. By this decision, the law of the state granting the decree governs the right of collateral attack in sister states. ${ }^{13}$

The principal effect of the Jolinson rule is that a single standard now measures the standing of all potential challengers of a particular divorce. The divorced couple themselves benefit most by this effect. For them the decision means that the strength of their decree does not vary with the rules of the states in which the third person may bring his attack. By looking to the law of the state which rendered their divorce, the divorcees can now predict whether a third party attack may reestablish previous marital obligations or jeopardize the legal status of subsequent marriages and families.

On the other hand, the Johnson decision may adversely affect the interested third person. He may be estopped from challenging a foreign adjudication by a rule of a state other than his own. Thus his interest is at the mercy of a foreign state which may wish to make its brand of divorce as attractive as possible by rendering it relatively attack-proof. This can be accomplished by the extension of "privity" to cover additional classes of third parties.14

To protect third persons, some limit should be put upon state courts' powers to insulate their divorce decrees. Third parties are, in most cases, suing to reclaim some property interest which has been injured or destroyed by the divorce decree. ${ }^{15}$ Can courts protect such interests and simultaneously prevent the injury to the primary parties which would result from the destruction of their status as divorcees? An analogous legal feat was accomplished in Estin v. Estin, ${ }^{16}$ a suit between the primary parties. There the Supreme Court held that while a Nevada divorce was a valid determination of the parties" status as divorcees, the decree could not affect a previous New York separation allotment to the wife. Thus the "status" aspect of the decree was divided from the "property" aspect.

marriage is a stranger to the divorce proceedings, late opinions of Florids indieate that the child would not be permitted to attack the divorce, since the child had a mere expectancy at the time of the divorce." 340 U. S. 581, 5SS (1951). For an evaluation of these grounds for the decision see Comment, Divorce Judisdielion by Consent of the Partics-Developinents Since "Sherrer i. Sherrer," 26 Inv. L. J. 380, 385 (1951).

13. For recent applications of this rule see Kienle v. Kienle, 107 N.Y.S. $2 d 239$ (N.Y. Sup. Ct. 1951) ; Cook v. Cook, 342 U.S. 126 (1951).

14. In all probability internal restraints will prevent this power being used to the utmost. It is notable that when the Nevada legislature removed the words "bona fide" from before the word "domicile," the Nevada Supreme Court construed them back in again. Latterner v. Latterner, 51 Nev. 285, 274 Pac. 194 (1929). Business interests, however, do promote "easy divorce" laws in some states. See Ingram \& Ballard, The Business of Iligratory Divoree in Nerada, 2 Law \& Conresor. Prom 302 (1935).

15. See, e.g., Loftis v. Dearing, 184 Tenn. 474, 201 S.W.2d 655 (1947); In re Davis' Estate, 38 Cal.App.2d 579, 101 P.2d 761 (1940); Smith v. Foto, 285 Ifich. 361, 280 N.W. 790 (1938).

16. 334 U.S. 541 (1948). 
In application, however, it is not always easy to recognize the distinction. Some divorce decrees contain explicit property settlements. ${ }^{17}$ In these cases it is relatively simple to determine what is meant by the "property" portion of the decree. But, where these settlements are lacking, the dissolution of the marriage may still have a resultant effect upon property. ${ }^{18}$ Here it is more difficult to delineate where "status" ends and "property" begins. A satisfactory pragmatic test might be: if a state court can satisfy the property claim without destroying the status effect of the foreign divorce, then the attack is upon the "property" aspect of the decree. In the Estin case the court could order the ex-husband to continue to pay the separation allotment without decreeing that he was still a married man. The attack then was on the "property" aspect. ${ }^{19}$ In the Johnson situation, on the other hand, the daughter could not be awarded the entire estate without decreeing, in effect, that the father was still married to his second wife at the time he "married" his third.

17. Such settlements, either contained in the decree or accompanying it, are most commonly court orders fixing alimony, payments for the support of minor children, the conveyance of certain tangible property over which the court has acquired jurisdiction, or the direction to distribute some mutual holding of the parties' in a stated manner. Sce Note, Marital Property and Migratory Divorce, 3 Stan. L. Rev. 622 (1951). A much noted case on the subject of an extraterritorial order to convey land is Fall v. Eastin, 215 U.S. 1 (1909).

18. Due to the time honored blending of status and property considerations in the legal relationship of marriage, there are invariably some indirect effects on these property rights when the marriage is dissolved (e.g., inheritance rights, right to support, mutual property holdings). Some of these may involve third persons. Adaums $v$. Adams, 154 Mass. 290, 28 N.E. 260 (1891). The situation in the Johnson case is an example of such an indirect effect upon a third person's interest without a specific court order on the matter. Further, the Johnson situation may be generalized to include casses where any statutory or testamentary heir of the husband who occupied that status at the time of the disputed divorce contests a subsequent wife's claim to the estate as a widow. These challengers do not have less of an interest prior to the decree than the daughter in the Johnson case. See note 12 supra. Again, several states still permit husband and wife to hold property "by the entirety" with a right of survivorship. Keezer, Marriage and Drvorce 24, $\$ 15$ (3d ed. 1946). Divorce, however converts the holding to one "in common." Id. at 582, §540. If, after a questionable divorce, the husband predeceases his ex-wife, one of her heirs might claim the entire property against the ex-husband's heirs asserting the divorce was invalid and the wife at the time of her death was the survivor and held the entire property. Still another instance occurs under the laws of some states which provide that a husband shall be liable for the antenuptial debts of his wife to the extent of the value of property he acquircd from her. See, e.g., 10 Mo. Rev. STAt. ANN. \$3391. Here a creditor of the wife, proceeding against the husband after a foreign divorce, may assert the decree's invalidity in order to maintain his prior claim, within the limits of the statute, against the husband.

Hypothetically, under the "family car" doctrine, or the husband's duty to supply his wife with "necessaries," a tort or contract obligation incurred by the wife after a question. able divorce might be maintained against the husband. The third party creditor would attempt to destroy the effect of the decree insofar as it served to terminate the husband's liability for these obligations.

19. 334 U.S. 541,548 (1948). 
Here there is a necessary dependence of the daughter's property claim upon the status effect of the divorce decree: to satisfy her claim the daughter must destroy her adversary's status of "widow" which is grounded on the validity of the status aspect of the divorce decree. Thus the attack was necessarily on the "status" aspect of the Florida decree."30

The rule in the Jolnnson case should not be applied to collateral attaclis directed to "property." Third party challenges could then be barred by foreign law only if a successful attack would destroy the divorcees' status. Such a limitation provides certainty for the immediate parties as to their status and yet allows third parties freedom from foreign bars in attaching the property effect of a divorce decree. Since the Estin case also declares intangible property adjudications to be in personam ${ }^{21}$ (as contrasted to the in rem character of a "status" adjudication"2), this limitation avoids conflict with the venerable doctrine that in an action in personam, a party in one state cannot be bound as a privy by the adjudication of another state's court. ${ }^{23}$

20. The suggested limitation of the Jolinson rule would of course encounter the criticism originally levelled at the Estirs "divisible divorce" result: that such a division does not further certainty but rather adds to the confusion (See Jaclson's dissent from the Estir opinion, 334 U.S. 541, 553). This argument asserts that one cannot be married for the purpose of some obligations and not for others. However, such a contention loses sight of the multiple roles of "marriage" and treats the collective term as an indivisible unit. Incidents of marriage have already disappeared in many states without any noticeable increment in the confusion. E.g., abolition of the right previously protected by actions for alienation of affection and criminal conversation, Coumsor, CASES 0:i Doxistic Relatrons 34 (1st ed. 1951) ; alterations of rights of dower, c.g., N.Y. Renz Prop. LAw. \$\$ 189, 190 (1945) ; Schneider \& Landesman, "Life, Liberty-and Dou'cr," 19 N.Y.U.L.Q. $343-69$ (1942).

21. 334 U.S. 541, 548-9 (1948). The Estis case involved an "intangible" property right and "[j]urisdiction over an intangible can indeed only arise from control or power over the persons whose relationships are the source of the rights and obligations." Id. at 548. The same rule applies to tangible property located outside the state Goovarcr, CONFLICT of LAws $\$ 138$ (3d ed. 1949). A court, however, may aequire jurisdiction over the rest of the property by virtue of its physical location within the forum state. In such a case the adjudication is said to be in rem. Restutesse:t, Jergse:Ts $\$ 2$, comment $a$ (1942).

22. "A decree of divorce so far as it affects the status of the parties is considered a judgment in rem and, if free from fraud and collusion, is binding on the whole world." 2 Frfesian, Judgaients $\$ 906$, (5th ed. 1925).

23. Bigelow v. Old Dominion Mining and Smelting Co., 225 U.S. 111 (1912).

The issue in this case was the res judicata effect of a New York procending against one or two joint tortfeasors (corporation promoters) in a subsequent suit on identionl charges against the other tortfeasor in Mlassachusetts. The Court held that an in personam decree could not bind one who was not in the jurisdiction of the court whether he be privy or not. This general principle was stated by the Ameriean Law Institute in the Restatenent, Conflict of Laws $\$ 450$ (d) as follows: "A judgment is valid only as against parties who were subject to the jurisdiction of the court which rendered the judgment and persons in privity with them. The law of a state where a valid judgment is rendered determines who are in privity with the parties to the judgment. If by 